\title{
THE TEACHER QUALIFICATION SCHEME: A CASE OF ALBANIA
}

\author{
PROBLEMS \\ OF EDUCATION \\ IN THE $21^{\text {st }}$ CENTURY \\ Volume 55, 2013
}

\author{
Tidita Abdurrahmani \\ Ministry of Education and Science, Institute of Educational Development, Albania \\ E-mail: abdurrahmanitidita@yahoo.com
}

\begin{abstract}
The study aims to analyse the results of "Teacher Qualification Exam" in Albania, and to link these results with teacher preparation curricula taught in public universities. The methodology of research includes desk research on the literature about curricula and teacher continuous professional development, elaboration of the results of the testing of 3064 teachers, analysis of the university teacher preparation curricula in terms of skills development, the elaboration of the results of questionnaires developed by novice teachers, and in depth interviews with students graduating from the education departments. As a result, the research shows the relationships amongst the curricula developed in the teacher preparation faculties in Albania, the poor results of novice teachers involved in the induction scheme, and the comparatively low results of teachers pertaining to the third category of the Qualification Scheme (novice teachers having no more than 5 years of teaching experience) in Albania. It is advisable to adopt a better professional development scheme.
\end{abstract}

Key words: desk research, novice teachers, teacher qualification.

\section{Introduction}

Pre-university education in Albania has gone through a period of thorough reforms in structure, content and organization as well as in the teacher professional development schemes. The structure of pre-university education in Albania passed from an eight year compulsory education into a nine year basic education system and from a four year high school profile-oriented system to a three year general high school one. The new law on pre-university education passed by the parliament on June 2013 foresees the passing of compulsory education onto a $6+3$ system, with primary education being extended over a period of six years of study and lower high school extending over three years.

Teacher professional development in Albania, like in other European countries, includes initial training in the universities, induction courses developing on the basis of a mentoring scheme, decentralised in-service training and the continuous professional development occurring within the school settings.

Teachers in Albania attend pre-service (initial) training in Tirana, Elbasan, Korça, Vlora, Shkodra and Gjirokastra universities, and at the Sports Academy. The teacher education faculties and departments within the university structures are responsible for organising and designing the programmes. In the midst of the evolving dynamics of teacher education in Europe, as well as with a strong understanding of the need for change, the teacher education reform was launched in 2010, although the stage was set a few years before. It consisted of a focus on key knowledge-based economy features such as innovation, education, training, lifelong learning, and the digital society.

In-service education in Albania has undergone recent reforms as well. One of them is out-sourcing the teacher in-service training to non-governmental service providers. The Committee for the Accreditation of the training modules set up with the aim of deliberalizing the training provision market and contributing to the fulfilment of the demands of teachers for inservice training. 
OF EDUCATIC

IN THE $21^{\text {st }}$ CENTURY Volume 55, 2013

A very recent initiative of the Ministry of Education and Science, with regards to the teaching profession, is the passing of the provision on "The Organisation and Conduct of Professional Practice for Teaching as a Regulated Profession”.

The regulation is a comprehensive guiding and explanatory document on what professional practice should, and will, look like in Albania. It sets out the roles and responsibilities of the actors involved, mentoring standards and responsibilities, application procedure guidelines, as well as applicant assessment procedures. This regulation foresees that teachers undergo a period of praxis for six months by the selected schools before they sit in for the state exam organized to allow them to receive the license as teachers. The new law on pre-university education foresees other forms of continuous professional development occurring in the school settings including professional networks, the implementation of a centralized Qualification Scheme, and the application of other schemes based on a bottom-up CPD approach. (Cidree yearbook, 2011).

Teacher Qualification in pre-university education in Albania is the process organized by the Ministry of Education and Science for the in-service assessment of teachers with a seniority record of teaching of 5, 10, and 20 years. This process leads to the certification of teachers according to three categories of qualification; namely qualified teacher, specialized teacher and master teacher. Once certified these teachers also receive a monthly increase in their salaries. Teacher training is currently considered as a state needed to improve and enhance the quality of education and educational reforms as well as one paving the path for the individuals to develop professionally. One of the main priorities of this platform is attracting and keeping high quality teachers to work by motivating them with new training schemes, based on achievements and not merely on length of service.

Despite the CPD (teacher Continuous Professional Development) schemes in place, the quality of education is dependent on much more than on how well prepared the curriculum is, how complete the legislation is or how responsible agencies are. In international testing programmes like PISA 2009 (the results of participation in Pisa 2012 are yet to be elaborated), Albania was still ranking below the OECD average. Pisa measures the preparation of students to face future challenges, their ability to analyze, ponder and communicate in an effective way, and their lifelong learning skills. In order to attain this the teacher is considered a key factor: "Teachers represent a critical tool to bring about change in the school. Their initial training and the continuous professional development are decisive factors in the attainment of the goals of the system" (OECD, 2004: p. 58). Results of the Qualification Exam for teachers in 2012 show that junior teachers perform worse compared to senior teachers, and the fault for this has to be tracked simultaneously in the initial training, induction, and in-service training schemes. This article deals with these variables from a context-based Albanian perspective and aims to come up with recommendations for policy-makers on a local and central level.

\section{Methodology of Research}

Combining results from two primary sources; pre-university education and university education, this paper also intertwines more than one research methodology. The Correlational Research involves quantitatively studying the relations between and among variables of the Teacher Qualification Process. The relationship between the variables has been examined without manipulating the data and without intentionally and forcefully aiming to set up a relationship between cause and effect. The methodology of the elaboration of the results of the Qualification Exam study is further explained in more detail in the context of this study. While for the analysis of the indicators of the teacher preparation faculties curricula the following methods were used:

1. Review of reports and evaluations of previous studies in this field. 
2. Analysis of undergraduate curriculum (lesson plans and subject syllabi of the last two academic years of a Bachelor and Master level in teacher preparation faculties in the country's three public universities in three different districts.)

3. Elaboration of the results of a survey conducted through an online questionnaire targeting senior students of public universities ( $76 \%$ of the sample of students) and of the private universities (24\%). To ensure the validity of the data, the questionnaire was sent via a link online to the e-mail addresses of students and the meeting place was set in conditions of complete anonymity.

The sample of the study was about 2000 students.

4. In-depth interviews with experts and higher education staff, 100 people.

\section{The Context of the Teacher Qualification Exam Study}

This study presents the main features of the achievements of pre-university education teachers who sat in for the national exam and were granted the entitlement of level III, II, and I category teachers in 2012. As the National Qualification Exam, as an evaluation method, has already entered its path and is being organized by the Ministry of Education and Science and the central subsidiary agencies for the fifth year in a row, this study is a follow up of study reports from previous years and, as such, it provides, amongst others, a comparative approach to teacher in-service performance over the years, besides attempting to come up with recommendations regarding the continuous professional development of teachers. Interpretation of the results of candidates in the Qualification 2012 and the study on teacher preparation faculties curricula are empirical studies conducted by the author.

In 2012, similar to the previous years, final evaluation of the teachers sitting in for the Qualification Exam was based on the combination of the output of several assessment tools including:

- Teacher portfolio

- Bonuses

- Test scores

Since the beginning of the process, regional education offices (REDs) and other educational offices $(\mathrm{EOs})^{1}$ started keeping professional records of teachers in their $5^{\text {th }}, 10^{\text {th }}$ or $20^{\text {th }}$ year of experience in the teaching profession and started compiling and archiving the professional portfolio for each teacher. The professional portfolio that the teachers submitted to the respective REDs or EOs consisted of:

1. Curriculum Vitae.

2. Copies of course certificates with credits received by the teachers.

3. Copies of certificates of academic titles received by the teachers.

4. Copies of foreign language exams teachers have sat in for.

5. Copies of certificates of mastery of ICT.

6. A sample annual teaching plan of a subject in a certain grade.

7. A document containing the student achievement goals in three levels for a certain chapter in a subject and a grade.

8. A sample test delivered to the students.

9. Sample pages of the diary and a complete daily planning, including the methods of achieving the lesson objectives.

1 In Albania the educational local units subsidiary to the Ministry of Education and Science and controlling the work done by schools are the Regional Directorates (REDs) and the Educational offices (EOs) 
Tidita ABDURRAHMANI. The Teacher Qualification Scheme: A Case of Albania

PROBLEMS

OF EDUCATION

IN THE $21^{\text {st }}$ CENTURY Volume 55,2013

10. A detailed curricular course project paper, together with a description of its accomplishment.

Elements evaluated in the teacher portfolio (3 points each) were:

1) The sample annual teaching plan of a subject in a particular grade.

2) Daily teaching plan of a subject in a particular grade.

3) A sample test delivered to the students.

4) The document containing the student achievement goals in three levels for a certain chapter in a subject and a grade.

5) The detailed curricular course project paper together with a description of its accomplishment.

The components of the teacher portfolio falling under the category of bonuses ( 5 points each) were:

1) Certificates of foreign languages, etc.

2) Certificates of academic titles.

3) Certificate with credits.

The portfolio was evaluated by commissions consisting of three people and functioning ad hoc by each of the REDs. Each of the required documents of the portfolio was valued at 0-3 points, while bonuses were evaluated with 5 points each if the certificate was filed. Thus, the entire portfolio was estimated at 30 points maximum.

The test was the main teacher evaluation tool comprising $70 \%$ of the total evaluation. A total of 37 different tests were designed. The test questions were on different levels and types. The test contained open-ended (yes and no) and multiple choice questions. The final evaluation score was estimated as a combination of the two components of evaluation, portfolio together with bonuses $(30 \%)$ and test $(70 \%)$. Five scales of evaluation were determined according to the set scheme: Excellent (A), Very Good (B) Good (C), Fair (D) and Poor (E). All candidates that resulted in failing at least one of the two parts of the test received a poor evaluation and failed the exam. All candidates passing the national test were provided with a certificate which indicated their evaluation score in numbers and letters.

Table 1. Number of participating teachers.

\begin{tabular}{llllll}
\hline Pre-university education level & Gender & First category & Second category & Third category & Total \\
\hline \multirow{3}{*}{ Pre-school education } & Female & 95 & 109 & 172 & 376 \\
\cline { 2 - 6 } & Male & 0 & 0 & 0 & 0 \\
\cline { 2 - 5 } & Total & 95 & 109 & 172 & 376 \\
\hline \multirow{3}{*}{$\begin{array}{l}\text { y years education } \\
\text { Primary cycle }\end{array}$} & Female & 267 & 200 & 263 & 730 \\
\cline { 2 - 5 } & Male & 65 & 16 & 16 & 97 \\
\hline \multirow{3}{*}{$\begin{array}{l}9 \text { years education } \\
\text { Lower secondary cycle }\end{array}$} & Total & 332 & 216 & 279 & 827 \\
\cline { 2 - 5 } & Female & 170 & 277 & 521 & 968 \\
\hline
\end{tabular}




\begin{tabular}{|c|c|c|c|c|c|c|}
\hline & & & & & & $\begin{array}{l}\text { PROBLEMS } \\
\text { OF EDUCATION } \\
\text { IN THE } 21^{\text {st }} \text { CENTURY } \\
\text { Volume 55, } 2013\end{array}$ \\
\hline \multirow{3}{*}{ General high school } & Female & 89 & 131 & 244 & 464 & 15 \\
\hline & Male & 43 & 26 & 65 & 134 & \\
\hline & Total & 132 & 157 & 309 & 598 & \\
\hline \multirow{3}{*}{ Vocational education } & Female & 7 & 5 & 9 & 21 & \\
\hline & Male & 2 & 0 & 1 & 3 & \\
\hline & Total & 9 & 5 & 10 & 24 & \\
\hline \multirow{3}{*}{ Social-cultural education } & Female & 7 & 10 & 9 & 26 & \\
\hline & Male & 4 & 3 & 6 & 13 & \\
\hline & Total & 11 & 13 & 15 & 39 & \\
\hline \multirow{3}{*}{ Total } & Female & 634 & 732 & 1218 & 2584 & \\
\hline & Male & 209 & 115 & 233 & 557 & \\
\hline & Total & 843 & 847 & 1451 & 3141 & \\
\hline
\end{tabular}

The data in Table 1 shows that the number of lower secondary level teachers of the compulsory education (nine grade education) participating in the Qualification Test was the largest. This is also due to the fact that the largest number of education employees is in this cycle of education. There can also be seen that there is an increasing demand to sit in for the attainment of the third category of qualification. This shows that there is a significant number of novices (junior teachers) with about five years of teaching experience working in the education system.

The teachers sitting in for the Qualification Exam are professionals with 5, 10 and 20 years of experience in the teaching profession. The data records of the qualification exam show a participation of 3141 teachers; of which 2584 females and 557 males. This distribution of teachers by gender shows that teaching still remains a profession reserved to females. Having almost half of the teachers registered to sit in for the third category exam (that after five years of teaching experience) shows that more and more youngsters are being recruited as teachers nowadays, while the number of experienced teachers (with 20 years of seniority) is on the decrease (here 847). Teachers in the Qualification process are distinguished from one another by their seniority rather than in terms of gender and less in terms of age. It is not possible to track in the Qualification process, the number of teachers coming from urban areas, and those coming from rural areas, because teachers with 5,10 , or 20 years of seniority are equally provided the opportunity to sit in for this exam, regardless of the area they come from.

\section{Results of Research (on the teacher qualification scheme)}

The results of the Qualification Exam of teachers for 2012 were elaborated along a series of variables which try to draw a linking line between aspects such as teacher seniority, formal education of teachers, and pedagogical and subject matter knowledge of tested teachers.

\section{Variable 1: Distribution by rating of teachers sitting in for the national qualification} test

Teacher performance was assessed by the percentage of points earned by teachers as a combination of $30 \%$ of the points earned through the portfolio assessment, and $70 \%$ of points earned by sitting in the national test. Performance assessment as a ratio between the achieved score and the maximum total score allows comparison of achievements between different groups, and over the years. 
Tidita ABDURRAHMANI. The Teacher Qualification Scheme: A Case of Albania

PROBLEMS

OF EDUCATION

IN THE $21^{\text {st }}$ CENTURY

Volume 55,2013

Figure 1 presents the ratio of the distribution of population to the evaluation scale of the achievements of the teachers sitting in for the qualification exam.

Qualification 2012

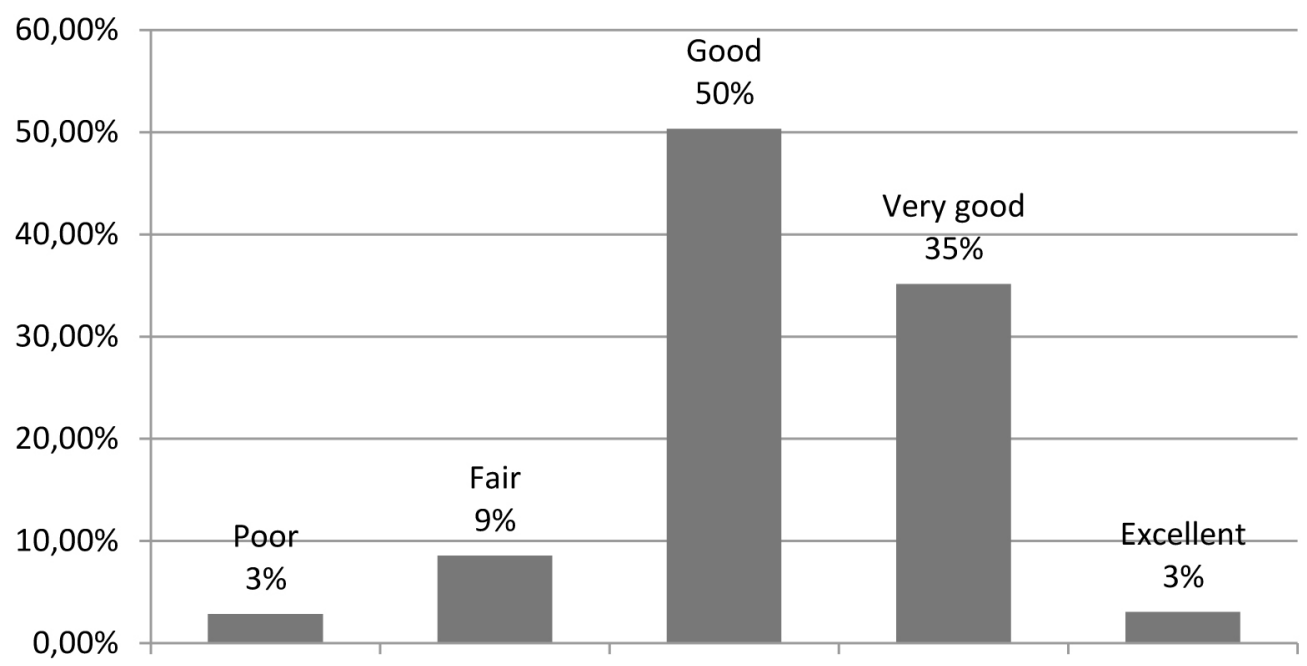

Figure 1: Distribution of national evaluation scale.

As seen from Figure 1, the largest group of teachers involved in the testing for qualification was that of the ones evaluated good (50\%) and very good (35\%), followed by the cluster of teachers who were assessed with poor, fair, and excellent results. This indicates that the assessed population perceived the test well thereby showing a preparation above the average.

Figure 2 and the database table attached to it show and juxtapose the distribution of the teacher achievements according to the evaluation scales starting from 2009 to 2012.

The data shows once again that the teacher achievements were concentrated on the very good and good scales of evaluation. There has been a marked stability to be traced over these years as far as the good rating is concerned. Half the number of the evaluated teachers remains at the average level throughout the years, while the number of those assessed with fair over the last two years, 2011, 2012 has undergone a significant reduction as compared to 2009 and 2010. There is an increase by more than $15 \%$ of those evaluated very good during the past two years, while the number of those evaluated poor has increased by almost $1 \%$ from 2011 and decreased by almost $2 \%$ compared to 2009 . The category of teachers rated as excellent holds a weight of $3.04 \%$, a value which compared to the last year, has increased by $1.23 \%$ and compared to 2010 has increased by $2.57 \%$. 


\section{Comparative achievements}

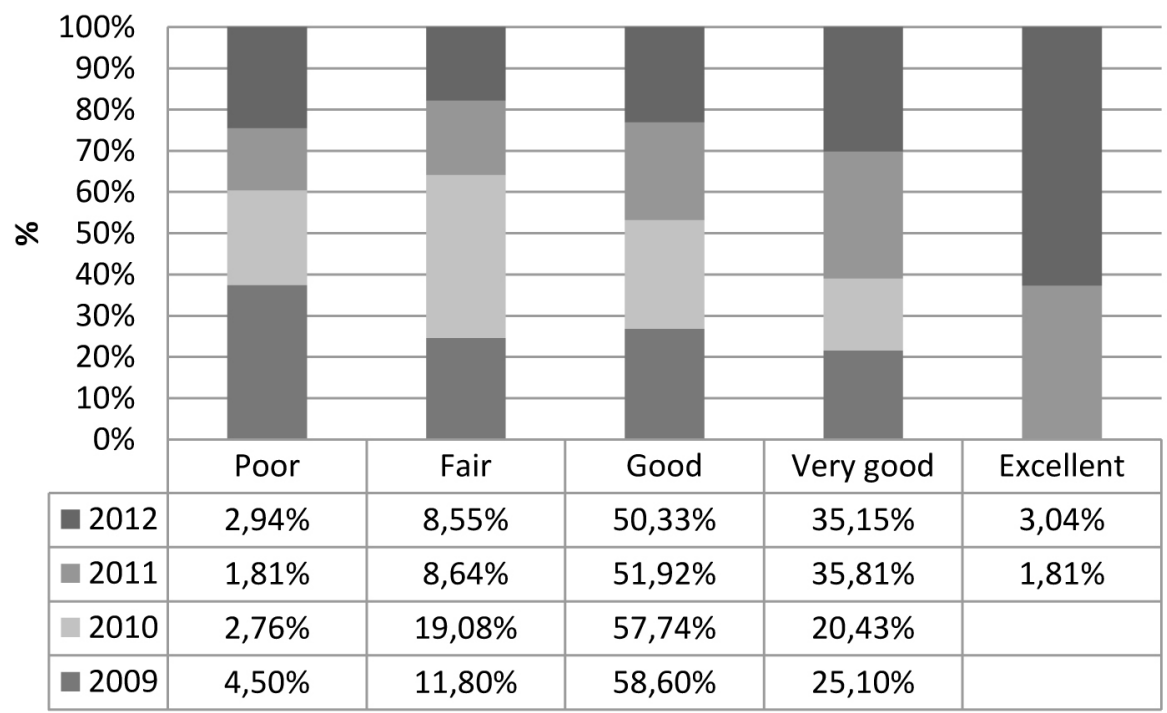

Figure 2: Distribution of achievements by evaluation scales for the years 20092011 (IZHA, Teacher Qualification Report 2009, 2010, 2011).

Variable 2: Teacher performance at pre-university education levels

Table 2 shows the ratio of the distribution of teachers for each level of pre-university education and in accordance with their ratings. Elaboration of the data coming from the table shows that the highest percentage rating for each level of pre-university education is in the evaluation good. Only socio-cultural and vocational education teachers show the highest percentage in the evaluation very good. Compared with the previous years the percentage of teachers evaluated very good in vocational education has increased by $15.2 \%$. None of the teachers of primary education and socio-cultural education received poor evaluation. Most of the $2.94 \%$ of teachers who have been evaluated poor was generally high school teachers and vocational education teachers.

Table 2. Distribution of teachers of each cycle by the evaluation scale (\%).

\begin{tabular}{llllll}
\hline Level & Poor & Fair & Good & Very good & Excellent \\
\hline Preschool education & 0.00 & 7.08 & 69.48 & 22.62 & 0.82 \\
\hline $\begin{array}{l}9 \text { years education } \\
\text { Primary cycle }\end{array}$ & 2.47 & 8.02 & 52.27 & 35.64 & 1.6 \\
\hline $\begin{array}{l}9 \text { years education } \\
\text { Lower secondary cycle }\end{array}$ & 3.12 & 8.86 & 46.65 & 38.34 & 3.03 \\
\hline High school & 5.07 & 10.32 & 44.75 & 33.92 & 5.94 \\
\hline Vocational education & 8.32 & 4.2 & 41.66 & 45.82 & 0.00 \\
\hline Socio-cultural education & 0.00 & 0.00 & 34.21 & 52.63 & 13.16 \\
\hline Total at national level & 2.94 & 8.55 & 50.33 & 35.15 & 3.04 \\
\hline
\end{tabular}


Tidita ABDURRAHMANI. The Teacher Qualification Scheme: A Case of Albania

PROBLEMS

OF EDUCATION

IN THE $21^{\text {st }}$ CENTURY

Volume 55, 2013

Table 2 also clearly shows that $3.04 \%$ of the tested population has been evaluated excellent, and the majority of this number consists of teachers of social-cultural education followed by general high school teachers. It is impressive to consider that in the group of high school teachers one can notice a high ratio of tested employees rated with excellent as well as a high number of teachers rated with poor. This shows that a large number of high school teachers are very well professionally trained and make all efforts to achieve good results, and at the same time there is also a number of teachers who have received very low scores indicating a low professional preparation and minimal efforts to advance professionally, but also absence of a well-thought pre-service and in service CPD scheme to be dwelt upon in more detail in the other parts of the study.

Achievements in the excellent evalution scale

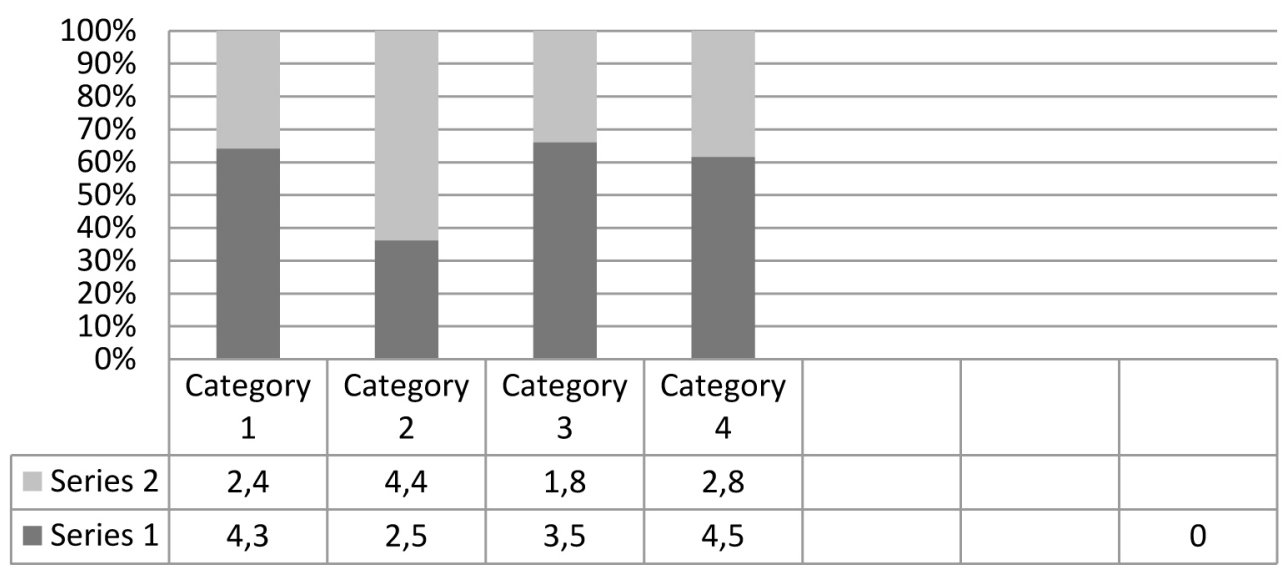

Figure 3: Distribution of teachers of each cycle according to the excellent ratings.

Figure 3 shows the distribution of teachers in each level of pre-university education according to the excellent evaluation scale. What impresses is that for almost every education cycle the percentage of teachers evaluated excellent has increased by $1.23 \%$ compared to the previous year. The largest increase is noticed in teachers of social- cultural education and general high schools. This also shows a clear correlation to the increase in postgraduate certificates, foreign language, and ICT mastery ones possessed by the teachers along the years.

Table 3. Percentage of teachers who gained bonus points for each educational cycle (\%).

\begin{tabular}{llll}
\hline Cycle & Masters/PhD & Foreign language & ICT \\
\hline Pre-school education & 0.81 & 2.72 & 39.24 \\
\hline 9 years education / Primary cycle & 0.86 & 7.27 & 57.34 \\
\hline 9 years education / Lower secondary cycle & 0.17 & 16.53 & 57.43 \\
\hline High school & 8.56 & 29.90 & 66.43 \\
\hline Vocational education & 4.16 & 16.66 & 66.66 \\
\hline Socio-cultural education & 15.79 & 50.00 & 39.47 \\
\hline Total & 2.87 & 15.34 & 56.70 \\
\hline
\end{tabular}


Table 3 shows the ratios of the percentages of teachers who possess a postgraduate certificate of masters/doctorate studies, certificates of mastery of a foreign language, and training certificates in ICT for each cycle of pre-university education. Correlatively to the distribution of the excellent ratings in teacher performance, the group of teachers in service in the sociocultural education schools stands for the highest percentage of teachers who have completed masters or PhD studies and possess a certificate (diploma) of these studies. Teachers serving in the vocational education stand for the highest percentage of the attested possessing foreign language mastery certificates; up to $50.00 \%$.

The table also shows that a high percentage of the attested teaching in vocational schools, general high schools, and 9-year grade schools possess an ICT certificate or credit certificates. In recent years priority has been given to teacher training and capacity building in the field of ICT in education.

Only 41 teachers or $1.34 \%$ of teachers involved in qualification showed possession of the three types of certificates (masters, foreign languages, and ICT). This ratio comprises of a) 2. $87 \%$ of teachers holding a master's/or doctorate degree; $1.29 \%$ more than last year. B) $15.34 \%$ of attested teachers having been certified for mastery of a foreign language; $2.74 \%$ more than last year, and c) $56.70 \%$ of attested teachers holding a certificate of mastery of ICT; $16.70 \%$ more than last year. Therefore, teachers tested this year benefited more points for bonuses compared to last year.

Variable 3: Teacher performance at qualification levels.

As previously shown, a total of 3064 teachers and school principals from the four levels of pre-university education participated in the qualification process of 2012, attendance thereby being higher than that of last year with about 415 more teachers.

Figure 3 clearly shows a distribution of teachers in percentage according to the qualification levels received. The highest percentage (46\%), standing for nearly half of the participating teachers, consists of teachers who were awarded the third category qualification. This category corresponds to a five year job experience. This fact is an indicator of the large number of new teachers currently working in our pre-university education system. The two other categories hold up for $27 \%$ of the total amount of teachers. The second category corresponds to 10 years of job experience while the third category corresponds to a 20 year job experience as teachers.

\section{Distribution of teachers according to the qualification category}



Figure 4: Percentage of the distribution of teachers according to the qualification categories. 
Tidita ABDURRAHMANI. The Teacher Qualification Scheme: A Case of Albania

PROBLEMS

OF EDUCATION

IN THE $21^{\text {st }}$ CENTURY

Volume 55, 2013

Table 4 shows the distribution in percentage of teachers holding a master's or doctor's degree, foreign languages, and ICT certificates in accordance with the categories they were being tested for.

Table 4. Percentage of the teachers holding certificates for each category (\%).

\begin{tabular}{llll}
\hline Qualification level & Masters/PhD & Foreign language & ICT \\
\hline Category one & 2.40 & 11.06 & 56.00 \\
Category two & 3.02 & 17.03 & 56.52 \\
Category three & 3.06 & 16.89 & 57.16 \\
Total & 2.87 & 15.34 & 56.70 \\
\hline
\end{tabular}

The highest percentage of those who have earned bonus points consists of teachers being tested to the third category. Specifically, $3.06 \%$ of the teachers tested to the third category hold a master's or a doctorate degree. This percentage is of $1.30 \%$ higher compared to last year's rating (Figure 5). So new teachers who have up to five years of experience have been more involved in attending postgraduate degrees during 2012 as compared to the previous years.

As far as holding ICT certificates is concerned, teachers of the three levels of qualification stand at almost the same percentage. Trainings in this field have been developed and disseminated to all pre-university education teachers with the same distribution rate regardless of age.

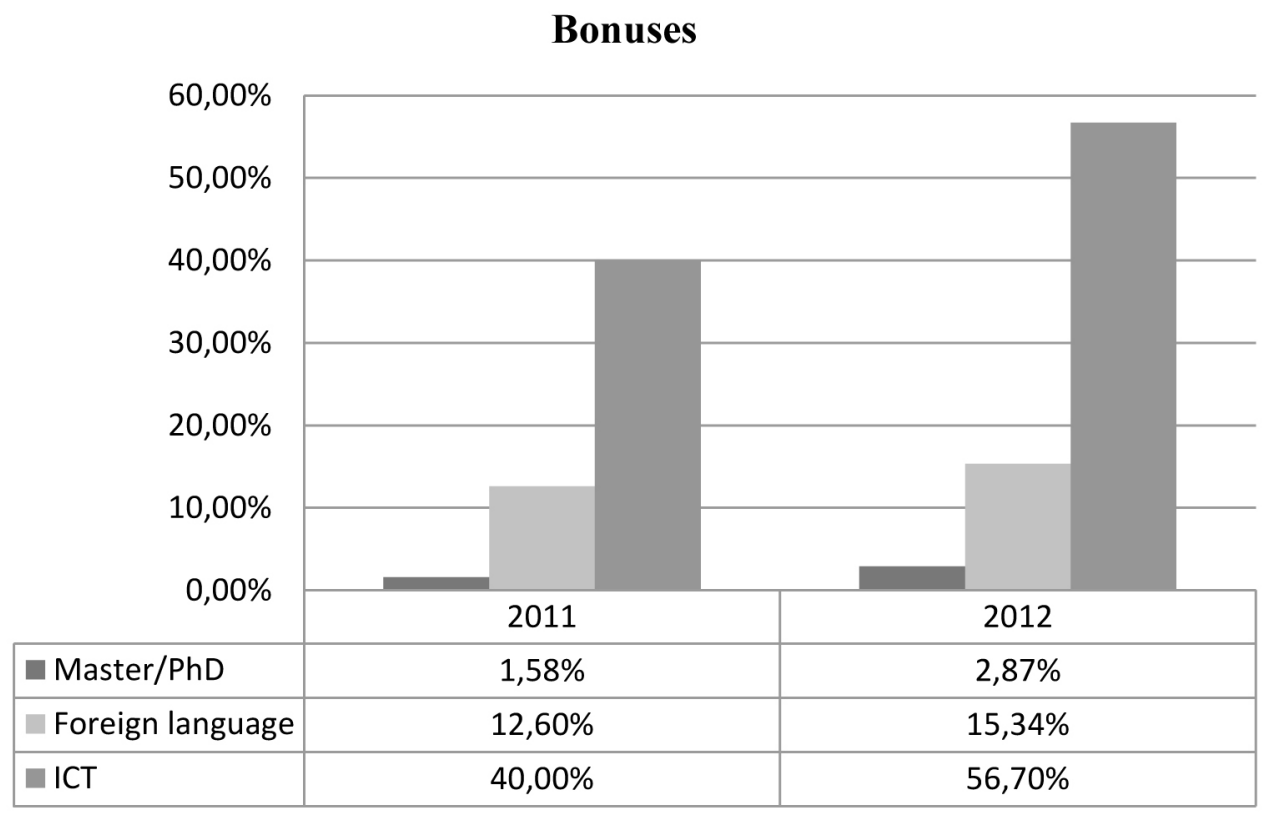

Figure 5: Comparative percentage of teachers who gained bonus points in the last couple of years (IZHA Qualification Report 2011).

Figure 5 clearly shows the comparative percentage of teachers who gained bonus points in the last couple of years. It is evident that in all the three cases where teachers have earned 
bonuses (be it certificate of masters/doctorate degree, certificate of mastery of a foreign language, and a certificate of training received in the field of ICT there is a significant increase as compared to the previous years.

Table 5. Distribution of the teachers for each evaluation scale (\%).

\begin{tabular}{llllll}
\hline Level qualification & Poor & Fair & Good & Very good & Excellent \\
\hline Category one & 0.87 & 7.83 & 44.67 & 42.04 & 4.58 \\
Category two & 2.29 & 7.24 & 50.03 & 37.08 & 3.36 \\
Category three & 4.57 & 9.76 & 53.76 & 29.95 & 1.20 \\
Total & 2.947 & 8.55 & 50.33 & 35.15 & 3.04 \\
\hline
\end{tabular}

In the general distribution of the tested teachers according to the evaluation scale, the evaluation good comprised the highest percentage with $50.33 \%$ on the national level. From Table 5 we can see that $53.76 \%$ of this percentage consists of teachers who have been tested to obtain the third category.

The same fact applies to the poor and fair evaluations. As regards very good and excellent evaluations, we can say that they belong mostly to teachers who took the test for the first and second category.

\section{Context of the Study: Initial Teacher Training and University Teacher Preparation Curricula}

New demands placed on the teaching profession are a reality for EU countries. Teachers all over Europe are increasingly required to help deliver skills, rather than information, and facilitate the learning process rather than be the 'centre of truth'. This new dynamic requires a range of new teaching methodologies, a focus on inclusiveness and the use of new Technologies.

In order to find out the relation between initial and in-service training of teachers, teacher education curricula, and in-service teacher training schemes, a study was conducted in 2011 with senior students and graduates from teacher education faculties. The study was conducted after the implementation of the new reformation agenda, that the teacher preparation faculties were going through. The main focus of the study was on:

1. Integration into the curriculum (Number of integrated disciplines contained in the curriculum. Mainstreaming cross themes and skills into the content of the curriculum.)

2. Developing a skill-based curriculum (Existence in the subject syllabi of objectives contributing to the formation of skills and attitudes in prospective students. Frequency of use of interactive methodology in the auditorium. Frequency in the use of Communication and Information Technology in teaching.)

3. Training through professional practice

- Report of professional practice and theory.

- The efficiency of the organization of professional practice. 


\section{PROBLEMS \\ OF EDUCATION \\ IN THE $21^{\text {st }}$ CENTURY \\ Volume 55, 2013 \\ The 2005 Agenda for Reformation}

In 2005, the initial teacher training programmes in Albania followed an agenda of reformation, undergoing restructuring in the context of Bologna Charter. In this context teacher training needed to be addressed through a national reform guided by policy documents with clear requirements and obligations, and which addressed teacher training both as a product and as a process. The Musai study in 2005 found that the :

'Academic university staff displayed a high level of involvement with the Bologna Process. The institutions of teacher education drafted the local reform agendas. The academic staff of the teacher preparation structured the curricula of teacher education. According to the study, through a platform drafted by the Ministry of Education and Sciences, they reformed the university curricula, opened new courses, accredited their curricula at national level and held discussions about the progress of the process in the future. However, the study revealed that the teacher-training faculties, or the higher courses of basic and secondary schools, did not have a clear platform for teacher educators to comply with the Bologna Charter.' (Musai et al., 2005:95-133).

Back in 2005, according to Musai, the traditional teaching schedule was a key issue pointed out by Albanian experts. According to them:

'Subjects were listed without a clear target concerning the different branches of study and the characteristics and competences which the students needed to acquire by completion of their studies. Selection of the teaching subjects was based on the 'offer' of the professors from each faculty and not on the 'demand'. This led to the creation of a very irregular structure and to difficulties in judging what these faculties were preparing. The need arose to focus on some key aspects. First of all, basic formation knowledge would cover subjects that teachers would teach and its weight on the teaching schedule would vary depending on what education level the teachers would teach. In addition, professional formation needed to be stressed, including the psychological' (Musai et al. 2005:114).

In addition, professional formation needed to be stressed, including the psychological, pedagogical, methodological, cultural and social aspects, and an applied research element. Another main element would be the teaching practice, which at the time was rated as being low profile in the teacher education programmes. Research also needed to become an integral part of the teaching curricula. Although teaching plans for teacher training faculties underwent restructuring, they did not demonstrate a clear target. They contained a lot of subjects, which were distributed empirically, or unified some subjects taught in partner institutions, which did not prove coherence with study-branch purposes and targets. There was no coherence among subjects that would allow for cross-curricular models.

'Lectures, exercises and seminars are divided in a way that creates the impression that the subjects intend to simply transmit knowledge and not construct new knowledge through discussion of different viewpoints, which would have made the lessons more attractive. A more rightful division in favour of exercises and seminars will be more acceptable if we take into consideration the fact that the student must deal with home work most of the time and come to the auditor to hold discussions and not reproduce lectures, or what is written in books' (Musai et al., 2005:125).

According to the key policy documents, teaching methodology did not resemble an interactive and student-focused model, and did not promote thinking skills, but rather fact retention. 'As with much of the rest of higher education, the style of teacher training is old fashioned and not very interactive: it tends to push facts and not encourage creative analytical thinking or problem solving. This style of teaching is thus perpetuated in schools once the students graduate' (Hatakenaka \& Thompson, 2006:23). 
Hatakenaka and Thompson added two more concerns to the issue of teacher education in Albania. According to them, the subject content was provided in narrow specialisms, which reduced the flexibility of the teacher to teach inter-related subjects. Moreover, teacher education in Albania lacked a standard curriculum and national standards.

'In part this is a reaction against any form of "central control" and the desire for "academic freedom" at all costs. However, the cost of this particular academic freedom is simply too high: Albania is a small nation that needs a degree of consistency about what pupils are taught in its schools. Further, the government is the main purchaser of the services of teachers and so it is reasonable for it to specify the content of teacher qualifications' (Hatakenaka \& Thompson, 2006:15).

Furthermore, these authors point out the limited contact that the universities have with schools, which limits the effectiveness of teaching practice. According to them, this is in part due to the reluctance of some senior university staff to follow the practices in schools in person. The position appears to have worsened in recent years, as schools no longer receive additional funding or any privileged status by agreeing to accept trainee students. The experts proposed that a separate 'Faculty of Education', offering a series of modules to be taken by prospective teachers, could be an alternative to the current system.

'The suggestion for Tirana University was to have a 3+1/2 arrangement, in which the $1 / 2$ would be for additional pedagogical courses. Such an arrangement would also allow the development of real subject based faculties in regional universities (not just teacher training ones), which could then play a broader regional development roles - not just for teacher training. On previous occasions, such proposals have met resistance within universities because of the restructuring implications; there is also a fear that insufficient numbers of students would choose the pedagogical modules' (Hatakenaka \& Thompson, 2006:14).

\section{Results of the Research (Teacher preparation faculties curricula)}

As pointed out in the context of the study on the Teacher preparation faculties curricula in order to find out the relation between initial and in-service training of teachers, teacher preparation curricula, and in-service teacher training schemes, a study was conducted in 2011 with 2000 senior students and graduates from teacher education faculties. The results of the elaboration of the variables were as follows:

\section{Indicator 1: Curriculum Integration}

There is a marked tendency to include in the programs of study subjects pertaining to the integrated disciplines. Some universities have introduced the teacher education programmes, topics or disciplines, which ensure a link to the praxis or the school system. However this trend is not prevalent in all programmes of study. The number of integrated disciplines is not large and does not ensure that their application develops based on the integration principles. An urge towards the development of an integrated curriculum comes out even in the presentation of master programmes of study with minor profiles in fields like arts, career orientation, and informatics.

\section{Indicator 2: Development of a skill-based curriculum and teaching methodologies used}

More than half of the novice teachers think that the university study programmes provide skills necessary for the formation and qualification of teachers. Questioned about the level to which the teacher preparation university curriculum develops in novice teachers the needed skills $65 \%$ of the respondents say that the program offers the ability to use a variety of teach- 
PROBLEMS

OF EDUCATION

IN THE $21^{\text {st }}$ CENTURY Volume 55,2013

24

ing methods, $56 \%$ of them say that the program offers the ability to use a variety of teaching methods, 53\% believe that the program offers techniques for managing successful classes and effective communication with parents. On the other hand parents feel less confident in the assessment of students' skills and ability to work in compliance with the social context.

The results of the questionnaire also assert that the methodology of teaching prevalent during the lecture classes is the traditional methodology with traces of interactive elements during which the lecturer holds the lecture and raises questions for discussion by the entire audience (confirmed by $38 \%$ of the students). Almost $26 \%$ of the students assert that, in the lecture halls, the authentic teacher centered traditional methodology during which the lecturer talks all the time or randomly poses questions to some of the students.

\section{Indicator 3: Professional Praxis}

The content of the teacher preparation faculties' curriculum is dictated in most cases by the university traditions and the lecturer's judgement about the importance, aim, and scope of the subject syllabi. The curriculum content is not dictated by real needs assessment analysis determined by the job market for the prospective teachers. Analysis of the lesson plans and subject syllabi show that in some cases the scientific content and the scientific training of teachers prevail as compared to the practical skills development and teaching methodology. The ratio between professional praxis hours and theoretical classes increases along with the years of study. Professional praxis classes vary from $1 / 3$ to $1 / 7$ of the total number of credits in the last year of the bachelor programme or the last year of the master programme. The majority of the students $(53 \%)$ confirm that the opportunity to observe the reality of classroom teaching is seldom or never.

The results of the initial teacher training questionnaire thus show that even after the implementation of the teacher preparation faculties reform in 2010 , there is yet much to be done in the teacher preparation university curricula and teaching methodology as far as skills development and curriculum integration is concerned.

\section{Discussion}

All context-based and international perspective-driven studies point to the fact that teachers matter in terms of the quality of education. Variability in teaching quality, however, is only explained to a limited degree by characteristics such as formal education, personal characteristics, and experience. When teacher preparedness is further analytically differentiated by types of knowledge, both subject matter, mastery, and pedagogical knowledge (particularly in the sense of subject matter didactics) are relevant.

Establishing coherent and clear goals and tasks for the entire system of teacher education and the systemic relationships of its components and contributions is one scenario. It is necessary to clarify which competences and attitudes prospective teachers should develop during initial teacher education. Initial teacher training standards need to be finalised and approved.

A second scenario focuses on linking teacher education and the teaching profession through a well developed knowledge base, and by studying the learning processes of students and the design of learning situations. These activities would enhance skills creation within the profession. Therefore, a key intervention includes changing how academic disciplines are introduced, organised and delivered, how they are transformed into human-knowledge structures and into clear teaching, studying and learning the realities in classrooms. The need for integrated curricula is a clear and immediate pre-requisite for this to happen. Efforts for reforms need to focus both on the pre-university and university level in order to ensure coherence and continuity.

Introducing subject-matter didactics which provide the scientific knowledge and empirical practices to be used in effective teaching and learning contexts is another scenario described 
in the document. This could lead to a lack of integration, however, and needs very careful consideration before it is adopted. An alternative to subject-matter didactics is by adopting a thematic approach, which has more potential for ensuring integration. The paper suggests that teacher education institutions should engage further in the production and design of scientifically validated practices and educational software that primarily lead to more efficient teaching and learning aids. This should be followed by establishing research-based structures.

Other scenarios include enabling teachers to act according to context-oriented dynamics, through developing a collaborative problem-solving capacity, by adding a research and development component to teacher education, by building partnerships between institutions of teacher education and schools, by introducing the concept of professional development schools, by better induction into the professional cultures of schools, by aiming at continuous development and systemic conceptions of in-service education, through the diversification of the professional tasks of teachers, by having a greater focus on teacher educators and through accreditation of teacher education programmes.

Currently, there is not enough research- and evaluation-based data to confirm which decisions are the best to take or to revise. It is advisable, in the context of reform implementation, that a careful process analysis and evaluation is carried out with the two-fold purpose of increasing stakeholders' participation and defining which potential path, or elements of it, are needed in our teacher education system.

\section{Conclusions}

Since student outcomes depend greatly on teacher quality, governments, local politicians, and school managers need to foster teachers' continuous professional development in order to cope effectively with ongoing changes and improve the quality of education.

Strengthening internal school conditions to promote teachers' professional development is considered an important prerequisite for addressing a continuous stream of changes in their environments (e.g. demographic changes, large-scale educational innovations, sociocultural renewal), the multidimensional restructuring demands to which they must respond, and the considerable external pressures arising from the tighter "output" controls introduced by accountability policies.

Low results among novice teachers sitting in for the five year qualification placement test mostly originate from the problems that can be traced to the university teacher preparation curriculum. The lack of opportunity to observe teaching in real classroom settings is reflected in the low results in the practical rubrics of the qualification test.

The focus of the scientific content of the subject syllabi in the university curricula accounts for the good results of the novice teachers in the scientific part of the qualification test and their failure to do well on the practical side of the text.

The failure of the education faculties teaching plan to equip students with the skills for working with the community accounts for the fairly poor results of the novice teachers in the rubrics of communication and ethics.

During the last three decades two basic teaching and learning paradigms have dominated professional discourse: constructivist-inspired teaching versus more structured (also often qualified as traditional) teaching. The two paradigms are the basis of divergent beliefs about teaching and learning.) The use of traditional teacher centred methodology in the lecture halls of education faculties accounts for the low average results of the methodological section of the test and the good results in the documentation section of the text (a rubric more oriented towards rigid memorization of facts).

The increased tendency to receive bonus points due to the certification from the accredited courses of language mastery programmes or post graduate programmes stands for the fact that teachers are feeling even more inclined to promoting their CPD, and the government should put much more effort into setting up well thought out CPD schemes. 
PROBLEMS

OF EDUCATION

IN THE $21^{\text {st }}$ CENTURY Volume 55,2013

Pedagogical training generally has a stronger effect than subject matter mastery. Professional development efforts, therefore, should not be merely based on a training paradigm implying a deficit-mastery model and consisting of one-shot professional development approaches.

The fact that teachers in Albania do better in the scientific section, rather than in the pedagogical and methodological part of the test is justified by the minimal percentage held by the professional praxis in the teacher education curricula.

The good results shown by the 1st qualification category teachers show that methodological skills in the teaching profession are aspects gained through experience, rather than through induction professional praxis periods.

\section{References}

Abdurrahmani, T., \& Boce, E. (2011). Pre-service, teacher training reform in Albania: a review. In P. Picard \& L. Ria (Eds): Beginning teachers: a challenge for educational systems - CIDREE Yearbook 2011 (pp. 209-222). Lyon, France: ENS de Lyon, Institut français de l'Éducation.

Buchberger, F. (1998). Teacher Education in Europe, European Education, (pp. 30).

Darling-Hammond, L. (1999). Teacher Quality and Student Achievement: A Review of State Policy Evidence. Seattle, WA: Center for the Study of Teaching and Policy, University of Washington, (pp. 59).

Developing coherent and system-wide induction programmes for beginning teachers: a handbook for policymakers (2010). European Commission Staff Working Document SEC 538 final.

Goldhaber, D. D., \& Brewer, D. J. (2000). Does Teacher Certification Matter? High School Teacher Certification Status and Student Achievement. Educational Evaluation and Policy Analysis, 22 (2), 129-145.

Hatakenaka, S., \& Thompson, Q. (2006). Albania Higher Education Report. Report submitted to the European Investment Bank. Retrieved from http://www.coe.int/t/dg4/highereducation/EHEA2010/ Tirana06/

HEAlbaniaWorldBankMarch\%202006_EN.pdf.

Instituti i Zhvillimit të Arsimit (2009). Raporti i kualifikimit të mësuesve [Teacher Qualification Report].

Instituti i Zhvillimit të Arsimit (2010). Raporti i kualifikimit të mësuesve. [Teacher Qualification Report].

Instituti i Zhvillimit të Arsimit (2011). Raporti i kualifikimit të mësuesve. [Teacher Qualification Report].

Musai, B. (2007). Standardet në Sistemin e Përgatitjes së Mësuesve[Standards in teacher education system]. Retrieved from: http://www.cde.edu.al/doc/S6 Stand e mesues SHQIP.pdf.

Musai, B. (2010). Formimi i Mësuesve në Përputhje me Kërkesat e Shoqërisë Së Dijes. [Teacher education in compliance with the knowledge society needs]. Retrieved From: http://www.lajme.gen. al/2010-07-06/formimi-i-mesuesve-ne-perputhje-me-kerkesat-e-shoqerise-se dijes.html.

Musai, B., Dhamo, M. Muka, P., \& Rapti, E. (2005). National report: Albania. In South East European Educational Co-operation Network. The Prospects of Teacher Education in South East Europe (pp. 95-133). Retrieved from http://www.seeeducoop.net/education_in/pdf/workshop/tesee/dokumenti/book/Albania.pdf.

OECD (2004). What makes school systems perform? Seeing school systems through the prism of PISA. OECD.

OECD (2007). Enhancing educational effectiveness through teachers' professional development. Field trial assessment plan: Proposed steps to finalize the questionnaires following the TALIS field trial. Group of National Experts for the International Survey for Teachers, Teaching and Learning.

Sahlberg, P., \& Boce, E. (2010). Are teachers teaching for a knowledge society? Teachers and Teaching, $16(1), 31-48$.

Schollaert, R. (2011). Continuing professional development for the 21 st century: setting the scene for teacher induction in a new era. In P. Picard \& L. Ria (Eds.), Beginning teachers: a challenge for educational systems - CIDREE Yearbook 2011 (pp. 9-28). Lyon, France: ENS de Lyon, Institut français de l'Éducation.

Tardif, M. (2001). Pre-service Teacher Training Programs: Outcomes of recent reforms and new trends towards effective professional training. Prepared for 2001 Pan-Canadian Education Research Program Symposium. Teacher and Educator Training Current Trends and Future Orientations. May 22-23, Université Laval, Quebec City.

Teacher Education in Europe, an Etuce Policy Paper (2008). Etuce Executive Board. 
Tidita ABDURRAHMANI. The Teacher Qualification Scheme: A Case of Albania

PROBLEMS

OF EDUCATION

IN THE $21^{\text {st }}$ CENTURY

Volume 55, 2013

Advised by Jūratė Armonienè, Vilnius University, Lithuania

Received: April 15, 2013

Accepted: June 18, 2013

Tidita Abdurrahmani

PhD., General Director, Institute of Educational Development, Ministry of Education and Science, Rr.Naim Frasheri Nr. 37, AL-1001 Tirana, Albania.

E-mail: abdurrahmanitidita@yahoo.com

Website: http:// www.izha.edu.al 